\title{
Implementasi Framework MVC Pada Pemodelan dan Pengembangan Sistem Informasi Masjid Berbasis Web
}

\author{
Guntur Maulana Zamroni ${ }^{1}$, Jefree Fahana ${ }^{2}$ \\ 1,2 Teknik Informatika - Universitas Ahmad Dahlan, Jl. Ahmad Yani (Ringroad Selatan) Tamanan Banguntapan Bantul Yogyakarta

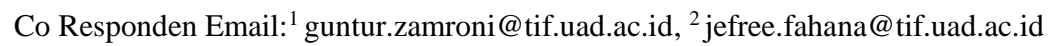

\author{
Article history \\ Received May 06, 2021 \\ Revised June 29, 2021 \\ Accepted June 29, 2021 \\ Available online June 30, 2021
}

Keywords

Mosque Information

System,

Website,

MVC
Riwayat

Diterima 06 May 2021

Revisi 29 Juni 2021

Disetujui 29 Juni 2021

Terbit 30 Juni 2021

Kata Kunci

Sistem Informasi Masjid, Website,

MVC

\begin{abstract}
Websites' ussages in the form of mosque information systems is one example of mosques' adaptation to technological developments. Management and financial reporting that were previously done manually with paper based can be replaced by managing them digitally. This will increase efficiency when mosque takmir require certain data. Lectures or event that previously carried out orally or face-to-face would be complemented by articles or videos. Mosques must be able to adapt and be able to keep up with digital technology developments and changes in society. However, not many mosques have used websites as information media or da'wah media. For that we need a mosque information system that has flexibility in terms of features. The author develops a web-based mosque information system application using the Model-View-Controller (MVC) architecture which can be used by mosque as a medium of information and da'wah to mosque congregations. Modified Waterfall model is used as a reference model for software development. Data collection in this study is divided into 2, namely the initial data collection using interviews, observations, and literature review, and data testing collection which is carried out using experiments for functional tests to test the feasibility of the system in terms of functionality. This research produces a mosque information system application. The system developed is designed in such way that the mosque takmir can make modifications in terms of features to easily adjust the needs of each mosque. Based on the functional test conducted, the feasibility percentage was obtained at $100 \%$. Thus it can be said that the system is feasible to use.
\end{abstract}

\begin{abstract}
Abstrak
Pengelolaan dan pelaporan keuangan masjid yang sebelumnya dilakukan secara paper based dapat diganti dengan melakukan pengelolaan secara digital. Hal ini akan meningkatkan efisiensi ketika pengurus takmir masjid memerlukan data tertentu. Masjid harus mampu menyesuaikan diri dan dapat mengikuti perkembangan teknologi digital dan perubahan di masyarakat. Akan tetapi belum banyak masjid yang sudah memanfaatkan website sebagai media informasi atau media dakwah. Untuk itu diperlukan sebuah sistem informasi masjid yang memiliki fleksibilitas dari sisi fitur. Penulis melakukan pengembangan aplikasi sistem informasi masjid berbasis web dengan menggunakan arsitektur Model-View-Controller (MVC) yang dapat digunakan oleh pengurus takmir masjid sebagai media informasi dan dakwah kepada jamaah masjid. Model Modified Waterfall digunakan sebagai model acuan pengembangan perangkat lunak. Pengumpulan data dalam penelitian ini terbagi menjadi 2, yaitu pengumpulan data awal dengan menggunakan wawancara, observasi, dan kajian literatur, dan pengumpulan data pengujian yang dilakukan dengan menggunakan eksperimen untuk functional test untuk menguji kelayakan sistem dari sisi fungsionalitas. Penelitian ini menghasilkan sebuah aplikasi sistem informasi masjid. Sistem informasi yang dikembangkan dirancang sedemikian rupa sehingga pengurus takmir masjid dapat melakukan modifikasi dari segi fitur menyesuaikan kebutuhan masjid masing-masing dengan mudah. Berdasarkan functional test yang dilakukan diperoleh persentase kelayakan sebesar $100 \%$. Dengan demikian dapat dikatakan bahwa sistem layak untuk digunakan.
\end{abstract}




\section{PENDAHULUAN}

Teknologi saat ini mengalami perkembangan yang sangat pesat, tidak terkecuali teknologi Internet. Teknologi Internet menawarkan kemudahan, antara lain kecepatan bertukar atau penyampaian informasi, menyimpan dan mengelola data organisasi, dan sebagai media promosi dan bisnis. Pengguna Internet di Indonesia selalu meningkat dari tahun ke tahun seperti yang diperlihatkan pada Gambar 1 (APJII, 2018). Dari hasil survey yang dilakukan oleh Asosiasi Penyelenggara Jasa Internet Indonesia (APJII) pada tahun 2019-2020 dapat diketahui bahwa $73,7 \%$ populasi Indonesia (196,71 Juta jiwa dari total populasi Indonesia sebesar 266,91 Juta jiwa) telah mengenal Internet (Irawan et al., 2020). Jumlah tersebut mengalami peningkatan dari tahun 2018 dengan jumlah pengguna Internet sebesar 171,17 Juta jiwa (APJII, 2018). Hal ini menunjukkan bahwa Internet bukan merupakan suatu hal yang asing bagi sebagian besar masyarakat Indonesia.

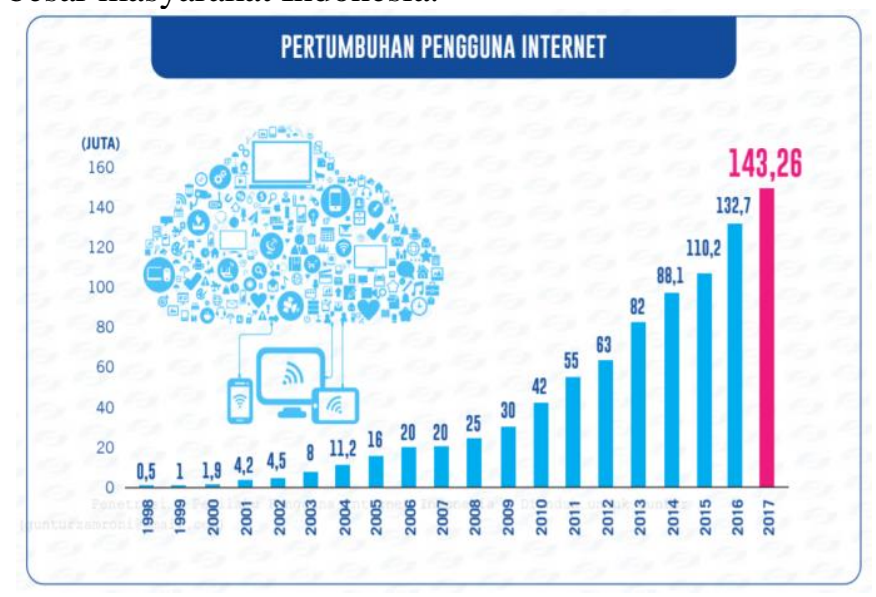

\section{Gambar 1. Infografis Pertumbuhan Pengguna Internet di Indonesia}

Website adalah salah satu teknologi yang memanfaatkan Internet. Teknologi website dimulai pada bulan Agustus 1991 oleh Tim Berners Lee dengan membuka sebuah website yang dapat diakses oleh khalayak umum. Semenjak saat itu website mengalami peningkatan cukup signifikan setiap tahunnya. Website memiliki tujuan awal untuk membantu komunikasi antar manusia yang berada pada lokasi yang berbeda-beda dapat melihat informasi yang ditampilkan (Triwidiyanto, 2010). Fungsi website lambat laun telah berkembang dan banyak digunakan pada berbagai sektor, mulai dari sektor pendidikan, ekonomi, kesehatan, gaya hidup, hiburan, sosial-politik, hingga berita (APJII, 2018) (Mubarok, 2018). Pemilik dan pengguna website pun juga tersebar pada berbagai sektor dan kalangan masyarakat, tidak terkecuali pengurus takmir masjid dan jamaah masjid.
Masjid harus dapat beradaptasi mengikuti perkembangan teknologi digital (Mukhtar, 2020). Masjid secara umum dapat diartikan sebagai sebuah rumah atau bangunan tempat bersembahyang orang Islam (Ali, 2009). Pemanfaatan website dalam bentuk sistem informasi manajemen masjid merupakan salah satu bentuk adaptasi masjid terhadap perkembangan teknologi. Sistem informasi adalah kombinasi dari manusia, fasilitas atau alat teknologi, media, prosedur, dan pengendalian yang bermaksud menata jaringan komunikasi yang penting, proses atas transaksi-transaksi tertentu dan rutin, membantu manajemen dan pemakai intern dan ekstern, dan menyediakan dasar pengambilan keputusan yang tepat (binus.ac.id, 2016). Scalia (2020) menambahkan bahwa sistem informasi merupakan sebuah perangkat lunak yang mengolah data mentah menjadi informasi yang berguna dan dapat digunakan untuk membantu pengambilan keputusan oleh sebuah organisasi. Sistem informasi masjid berbasis web dapat dikembangkan dengan menggunakan framework MVC. MVC adalah satu pola dalam pengembangan perangkat lunak. MVC memisahkan sebuah aplikasi menjadi 3 bagian yang terpisah secara logika tetapi tetap saling berhubungan, yaitu Model, View, dan Controller (Wahyudi, 2015). MVC member keuntungan dalam hal pengelolaan kode program (Iyawe, 2019).

Rokhman (2017) menyatakan bahwa sistem informasi masjid dapat meningkatkan pelayanan masjid. Pengelolaan dan pelaporan keuangan masjid yang sebelumnya dilakukan secara manual (paper based) dapat diganti dengan melakukan pengelolaan secara digital (computer based). Hal ini tentu saja akan meningkatkan efisiensi ketika pengurus takmir masjid memerlukan data tertentu (Fahruddin \& Azam, n.d.) (Prabowo et al., 2013). Kajian-kajian masjid yang sebelumnya hanya dapat dilakukan secara lisan atau tatap muka secara langsung akan dapat dilengkapi dengan menggunakan kajiankajian dalam bentuk artikel atau video. Akan tetapi belum banyak masjid yang sudah memanfaatkan website sebagai media informasi atau media dakwah. Apabila terdapat masjid yang sudah memanfaatkan website sebagai media komunikasi dan dakwah, umumnya fitur yang ada akan berbeda dari 1 masjid dengan masjid yang lain menyesuaikan kebutuhan tiap masjid.

Berdasarkan paparan di atas, penulis melakukan penelitian terkait pengembangan sistem informasi masjid berbasis web dengan menggunakan framework MVC. Sistem informasi yang dikembangkan akan dirancang sedemikian rupa sehingga pengurus takmir masjid dapat melakukan modifikasi dari segi fitur aplikasi menyesuaikan kebutuhan masjid masing-masing. 


\section{METODE DAN ALAT PENELITIAN}

Tujuan dari penelitian ini adalah untuk membuat model dan mengembangkan sistem informasi masjid. Untuk mencapai tujuan penelitian diperlukan suatu panduan dari tahapan penelitian berikut alat-alat yang diperlukan pada setiap tahapan.

\section{A. Metode Penelitian}

Penulis menggunakan model Modified Waterfall sebagai acuan metode penelitian seperti yang diperlihatkan pada Gambar 2 (Rayo, 2015). Model Modified Waterfall memiliki beberapa tahapan, antara lain: pengumpulan kebutuhan siste, analisis kebutuhan, desain, implementasi kode program, dan pengujian sistem.

1) Pengumpulan Kebutuhan: Penulis memulai penelitian dengan melakukan pengumpulan kebutuhan. Pada tahap ini penulis menggunakan metode pengumpulan data primer, yaitu: wawancara, observasi, dan pengumpulan data sekunder dengan menggunakan kajian literature dari artikel, buku, ataupun sumber Internet.

2) Analisis: Data hasil pengumpulan data dianalisis untuk digunakan sebagai bahan acuan pada tahap desain. Pada tahap ini diketahui kebutuhan user dan kebutuhan sistem.

3) Desain: Pada tahap desain dibuat beberapa diagram seperti use case diagram yang digunakan untuk memodelkan interaksi antara aktor dengan sistem secara visual, flow chart dan sequence diagram digunakan untuk memodelkan alur aplikasi dan proses bisnis aplikasi, desain antar muka (user interface design) dan class diagram sebagai acuan implementasi kode program.

4) Implementasi: Pada tahap ini dilakukan implementasi kode program berdasarkan desain yang telah dibuat pada tahap sebelumnya. Penulis melakukan pengembangan sistem menggunakan CodeIgniter dan PHP.

5) Pengujian: Pada tahap terakhir akan dilakukan pengujian. Pengujian dilakukan menggunakan functional test dengan pendekatan black box testing.

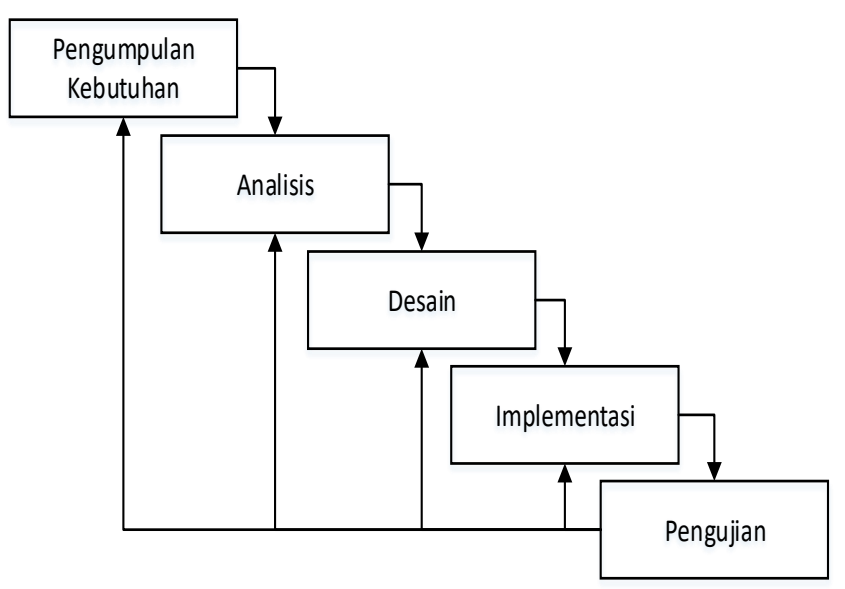

Gambar 2. Model Modified Waterfall

\section{B. Alat Penelitian}

Alat penelitian yang digunakan pada penelitian ini terbagi menjadi 2, yaitu perangkat keras dan perangkat lunak. Tabel 1 dan Tabel 2 menunjukkan alat penelitian yang digunakan pada penelitian ini.

TABEL I KEBUTUHAN PERANGKAT KERAS

\begin{tabular}{ccc}
\hline No. & Nama Perangkat Keras & Deskripsi \\
\hline 1. & Laptop Asus Vivobook S14 & Perangkat untuk pengembangan dan pengujian aplikasi \\
2. & Desktop & Perangkat untuk pengembangan dan pengujianaplikasi \\
\hline
\end{tabular}

\section{TABEL II KEBUTUHAN PERANGKAT LUNAK}

\begin{tabular}{cll}
\hline No. & \multicolumn{1}{c}{ Nama Perangkat Lunak } & \multicolumn{1}{c}{ Keterangan } \\
\hline 1. & Windows 10 & Sistem operasi perangkat laptop \\
2. & XAMPP & Perangkat lunak untuk pengembangan database \\
3. & Sublime Text Editor & Perangkat lunak untuk pengembangan aplikasi \\
4. & Google Chrome & Perangkat lunak untuk pengembangan aplikasi \\
5. & Microsoft Word 2013 & Perangkat lunak untuk dokumentasi \\
6. & Enterprise Architect & Perangkat lunak untuk pemodelan \\
\hline
\end{tabular}

\section{Metode Pengolahan Data Pengujian}


Pengujian functional test dilakukan untuk mengetahui apakah sistem yang dibangun berjalan sesuai harapan atau tidak. Penulis membuat tabel pengujian dalam yang berisi berbagai macam scenario. Dari hasil pengujian dapat diketahui persentase kelayakan yang dihitung dengan menggunakan Formula (1).

$\frac{\text { Nilai Hasil Pengujian }}{\text { Nilai Maksimal }} \times 100 \%$

Persentase Kelayakan (\%) $=$

\section{HASIL DAN PEMBAHASAN}

\section{A. Pengumpulan dan Analisis Kebutuhan}

Pengumpulan kebutuhan dilakukan untuk mengumpulkan data berkaitan dengan sistem informasi masjid. Dari hasil wawancara dan observasi yang dilakukan, diketahui beberapa informasi dan pelayanan yang umumnya disediakan oleh masjid dan diperlukan oleh masyarakat, antara lain menampilkan informasi mengenai masjid dan takmir, menampilkan laporan keuangan, menampilkan jadwal-jadwal kegiatan masjid, menampilkan daftar jamaah, dan lain sebagainya.
Terdapat 2 pengguna sistem ini, yaitu pengunjung dan admin. Pengunjung website dan admin akan memiliki wewenang yang berbeda-beda. Berdasarkan informasi tersebut dibuat beberapa diagram untuk memodelkan sistem.

\section{B. Desain}

Pada tahap ini dilakukan pemodelan mengenai sistem yang dikembangkan. Terdapat beberapa diagram pemodelan yang dibuat, antara lain use case diagram, activity diagram, class diagram, data model, dan desain user interface.

\section{1) Use Case Diagram}

Gambar 3 menunjukkan use case diagram sistem informasi masjid. Dari Gambar 3 dapat diketahui bahwa terdapat 2 aktor yang berinteraksi dengan sistem, yaitu admin dan pengunjung. Admin dan pengunjung memiliki hak yang berbeda. Admin dapat mengelola informasi yang tersedia di sistem, seperti: profil masjid, data jamaah dan penerima zakat, galeri, jadwal, berita masjid, dan laporan keuangan. Pengunjung hanya dapat melihat profil masjid, jadwal, galeri, berita masjid, laporan keuangan, dan informasi kontak masjid.

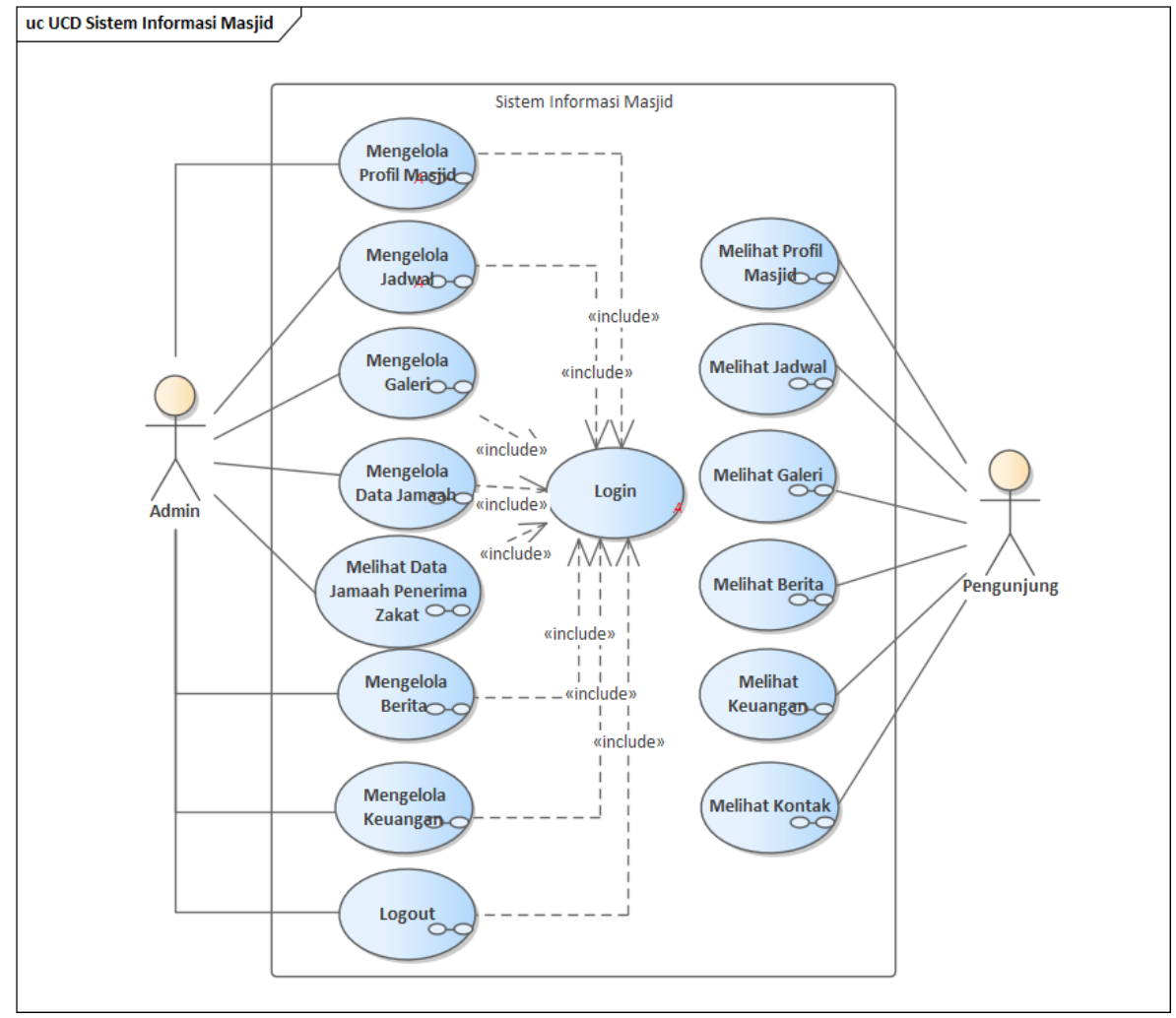

Gambar 3. Use Case Diagram Sistem Informasi Masjid 


\section{2) Activity Diagram}

Activity diagram dibuat untuk menjelaskan alur dari setiap use case. Secara keseluruhan terdapat 15 activity diagram berdasarkan use case diagram yang telah dibuat. Beberapa activity diagram dapat dilihat pada Gambar 4 yang menunjukkan activity diagram untuk proses login admin dan Gambar 5 yang menunjukkan pengelolaan jadwal kegiatan masjid. Pada Gambar 4 dapat dilihat bahwa admin perlu untuk memasukkan ID username dan password untuk kemudian diverifikasi oleh sistem.
Apabila verifikasi tidak sesuai, maka admin akan diarahkan kembali ke menu login. Apabila proses verifikasi sesuai, maka admin akan diarahkan ke menu dashboard. Gambar 5 menunjukkan proses admin dalam mengelola jadwal kegiatan. Setelah admin berhasil melakukan login dan masuk ke menu dashboard, admin dapat memilih menu jadwal. Di dalam menu jadwal terdapat beberapa pilihan seperti mengelola jadwal imam dan khatib shalat Jumat, jadwal kajian, jadwal TPA, dan jadwal kegiatan lainnya.

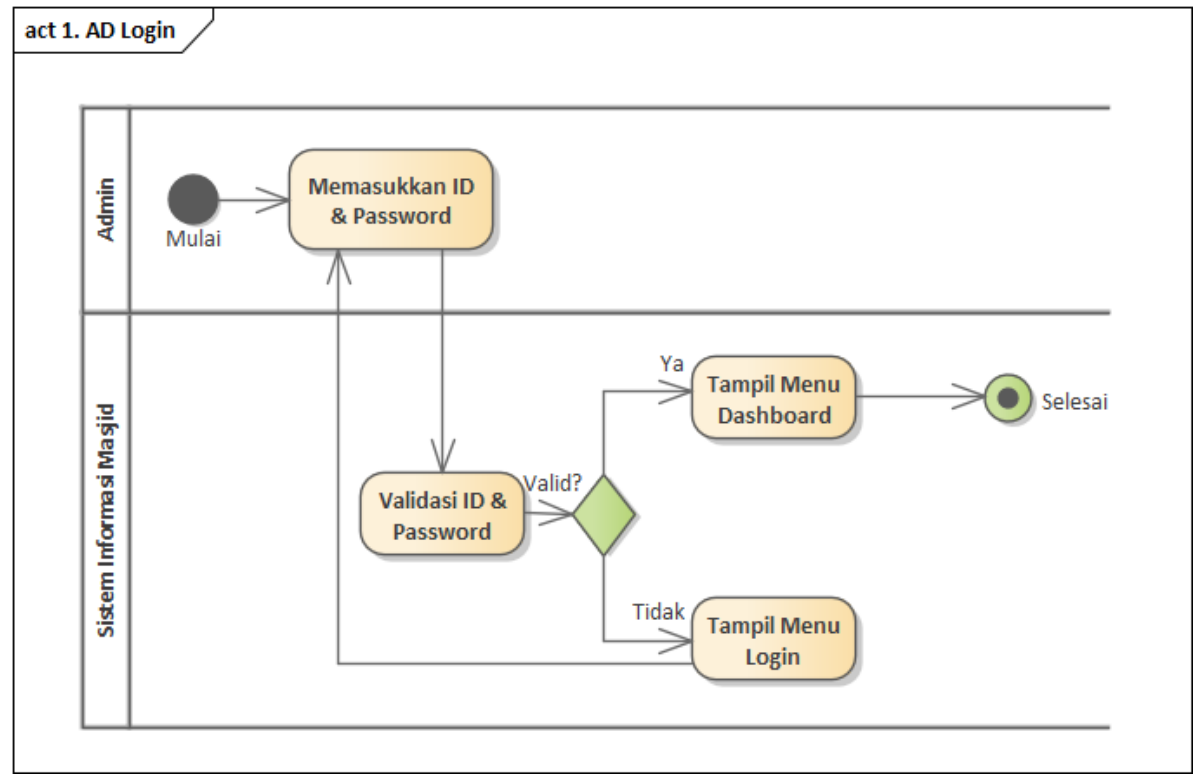

Gambar 4. Activity Diagram Login Admin

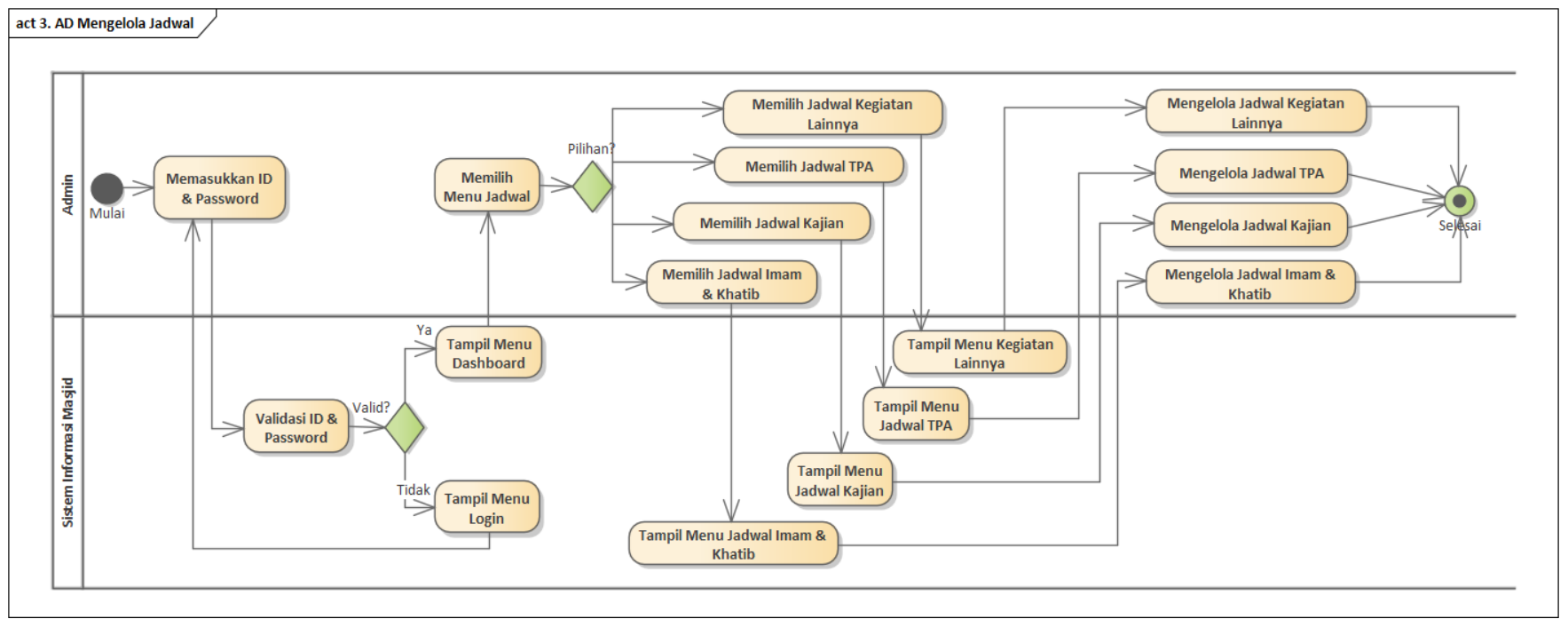

Gambar 5. Activity Diagram Mengelola Jadwal 


\section{3) Class Diagram}

Gambar 6 dan Gambar 7 menunjukkan class diagram sistem informasi masjid. Dari gambar dapat diketahui implementasi dari arsitektur MVC dalam sistem. Sistem menggunakan 2 view, yaitu view untuk admin dan view untuk pengunjung. View pengunjung dan view admin terhubung dengan controller untuk dapat mengakses model dan database. Terdapat 11 model yang menghubungkan antara controller pengunjung dan controller admin dengan database. Controller admin terhubung dengan model autentikasi login untuk admin antara lain Masjid, Jadwal, Galeri, Jamaah, Berita, dan Keuangan. Sedangkan controller pengunjung terhubung dengan model Home, Jadwal, Berita, dan Keuangan.

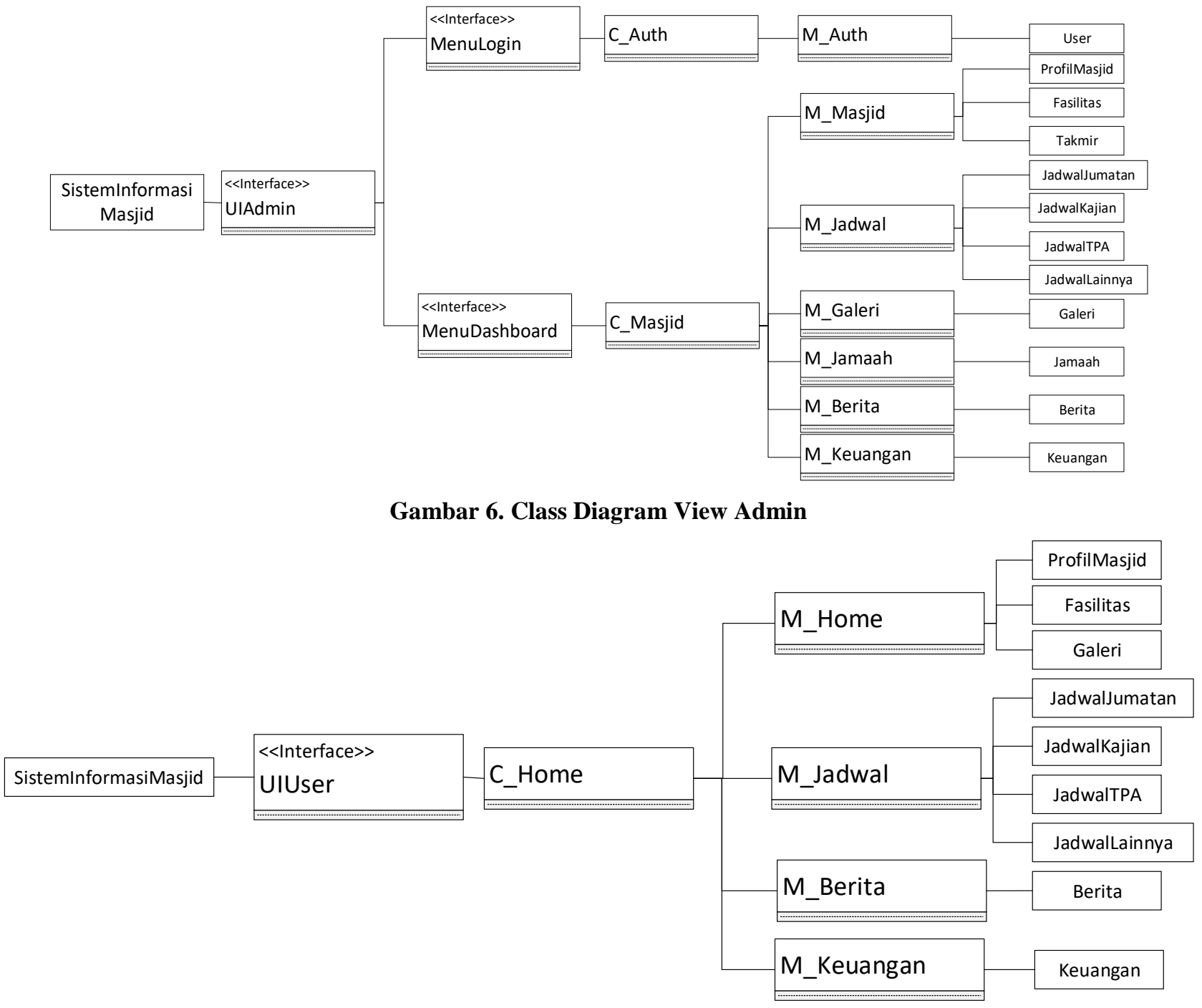

Gambar 7. Class Diagram View User

\section{4) Data Model}

Gambar 8 menunjukkan data model dari sistem informasi masjid yang dibangun. Terdapat 13 tabel database pada sistem informasi ini, yaitu tabel user, masjid, jamaah, socmed, fasilitas, takmir, galeri, keuangan, berita, jadwal jumatan, jadwal kajian, jadwal tpa, jadwal lainnya. 


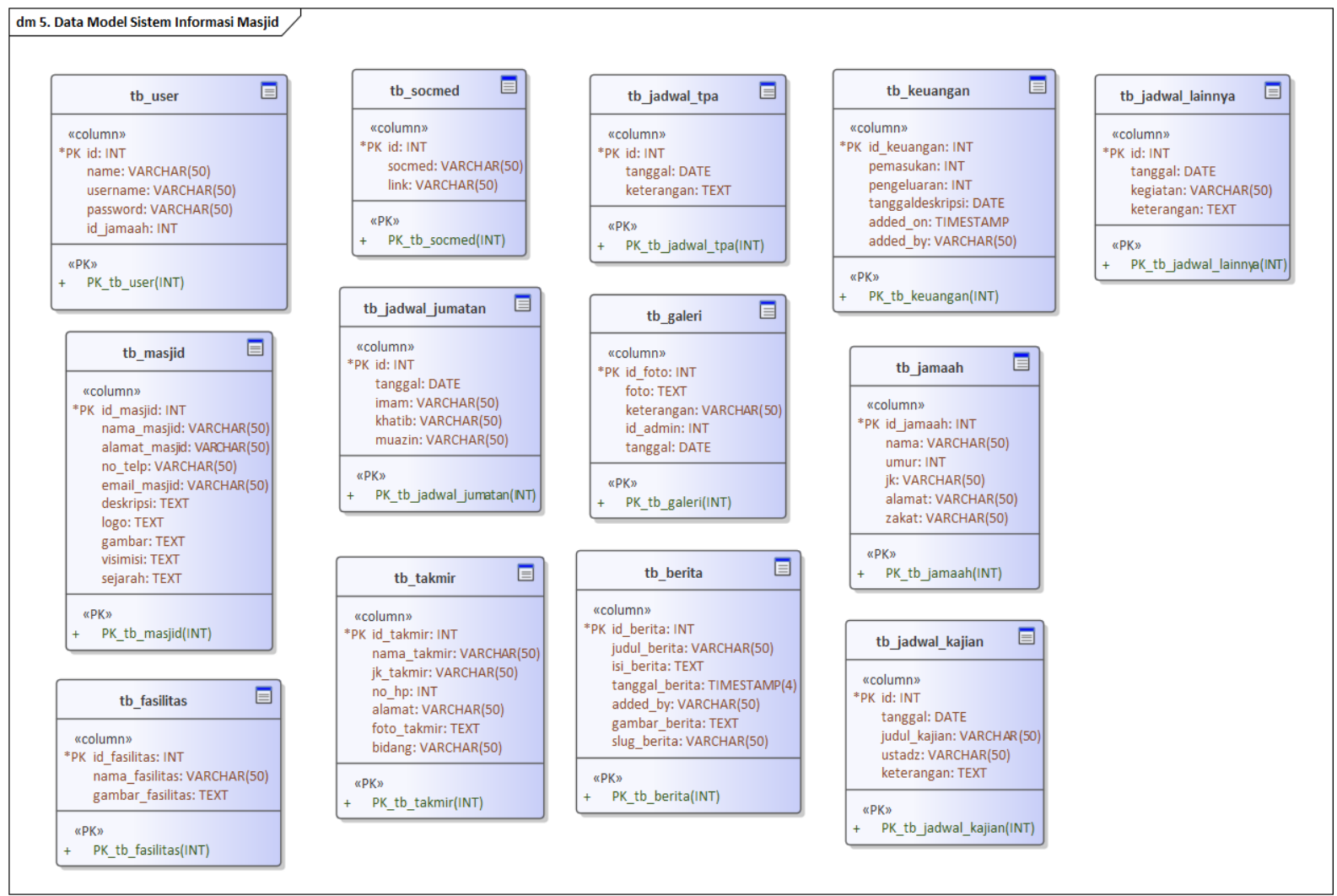

Gambar 8. Data Model Sistem Informasi Masjid

5) Desain User Interface

Desain user interface dibuat berdasarkan hasil diagram pemodelan yang dibuat pada tahap sebelumnya. Dari use case diagram yang dibuat dapat diketahui beberapa fitur yang diperlukan pada user interface sistem. User interface terbagi menjadi 2, yaitu menu utama untuk pengunjung dan menu back end untuk admin seperti pada Gambar 9.
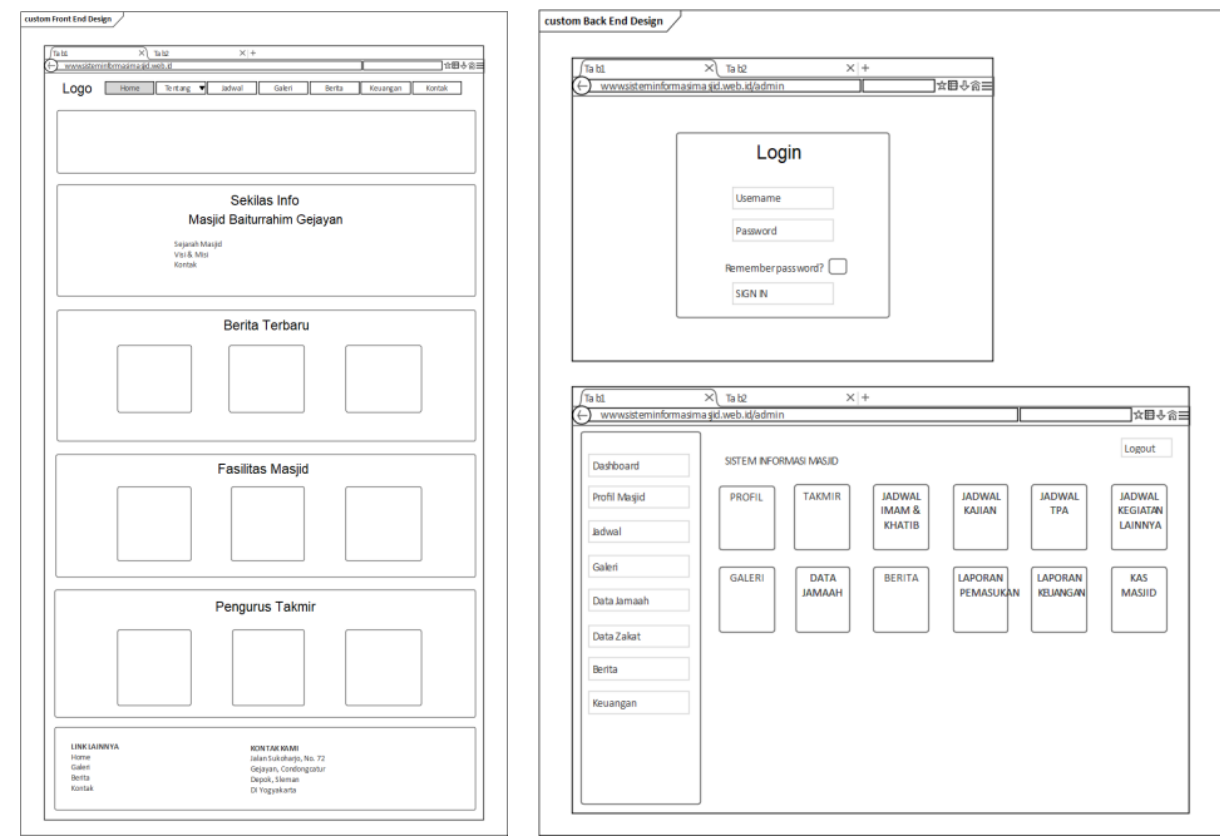

Gambar 9. Desain User Interface 
JIKA (Jurnal Informatika) Universitas Muhammadiyah Tangerang Tangerang, Juni 2021, pp 184 - 194

\section{Implementasi}

Implementasi kode program dibuat dengan Bahasa pemrograman PHP dan framework CodeIginiter. Gambar 10 menunjukkan tampilan home. Pada tampilan home terdapat informasi seperti akun media sosial masjid dan beberapa menu seperti informasi mengenai masjid, jadwal kegiatan masjid, galeri, berita, laporan keuangan, dan informasi kontak masjid. Apabila pengunjung memilih menu tentang masjid, jadwal, dan keuangan akan muncul sub menu seperti yang dapat dilihat pada Gambar 11. Gambar 12 menunjukkan tampilan laporan keuangan yang dapat diakses oleh pengunjung website. Pengunjung dapat melihat laporan kas keuangan masjid. Pada menu tersebut terdapat informasi mengenai tanggal input laporan, nominal debit atau kredit, sisa saldo, dan keterangan dana.

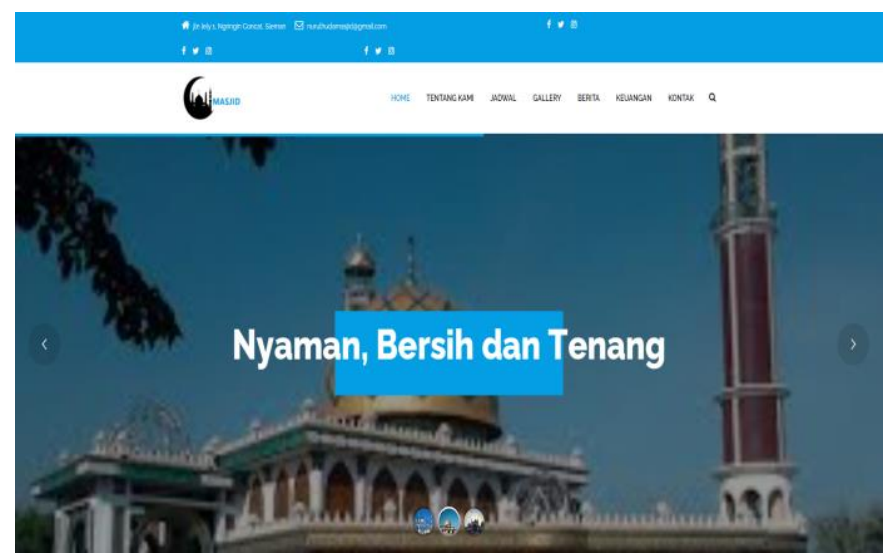

Gambar 10. Tampilan Home

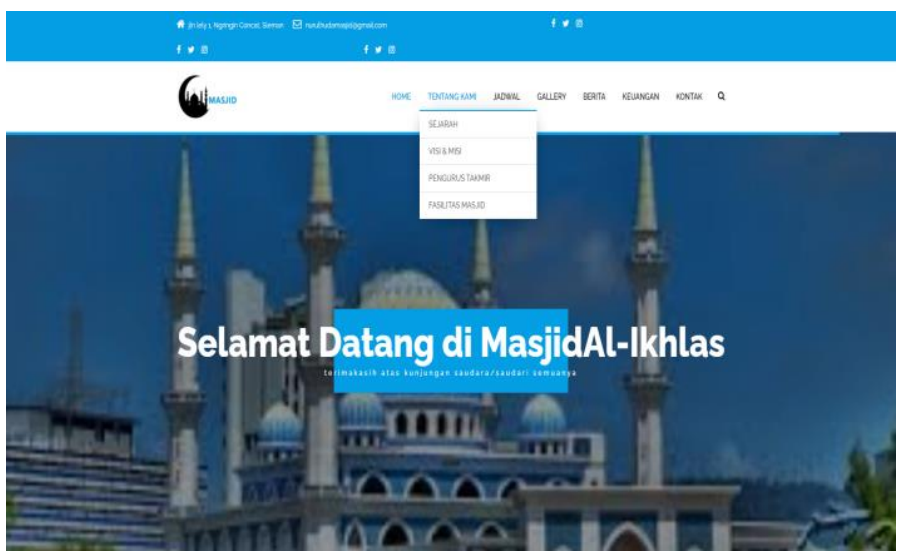

Gambar 11. Tampilan Submenu
$P$ ISSN : 2549-0710

E ISSN : 2722-2713

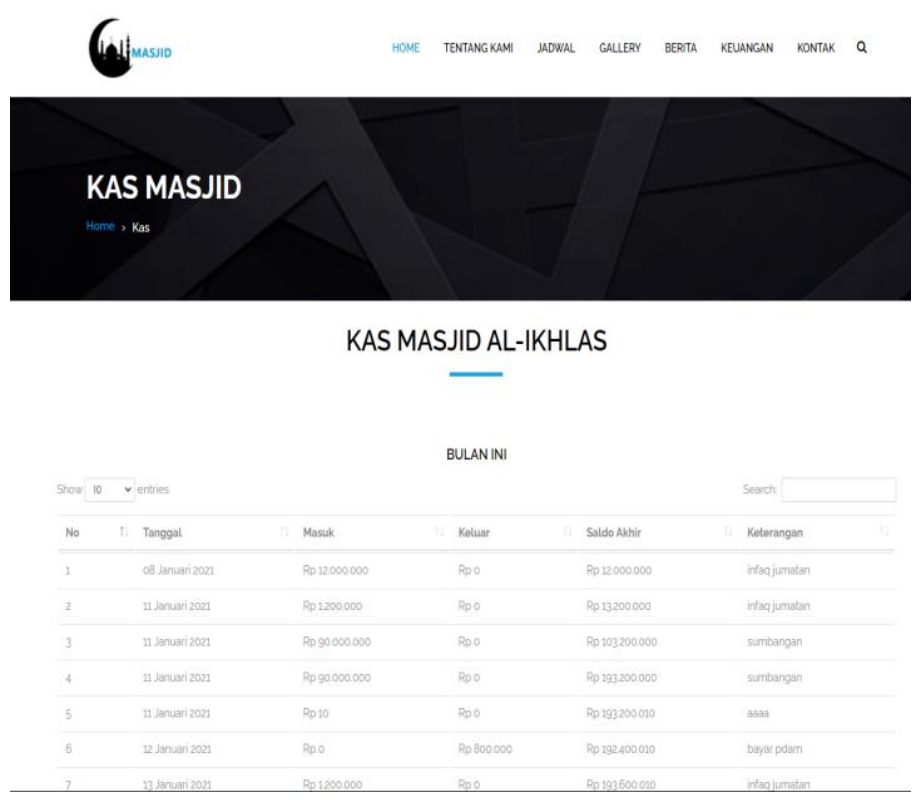

Gambar 12. Tampilan Laporan Keuangan

Gambar 13 menunjukkan tampilan login admin. Admin akan diminta untuk menginputkan username dan password. Pada tampilan tersebut juga disediakan opsi untuk mengingat password apabila admin tidak ingin memasukkan username dan password di kemudian hari. Setelah proses verifikasi username dan password berhasil, admin akan diarahkan ke tampilan dashboard admin seperti pada Gambar 14. Pada dashboard terdapat beberapa menu yang dapat dipilih oleh admin untuk mengelola informasi, antara lain profil masjid, takmir masjid, jadwal imam \& khatib shalat Jumat, jadwal kajian, jadwal TPA, jadwal kegiatan lain, galeri, data jamaah dan penerima zakat, berita, laporan pemasukan, laporan pengeluaran, dan laporan kas masjid. Tombol logout juga disediakan apabila admin ingin untuk logout dari sistem.

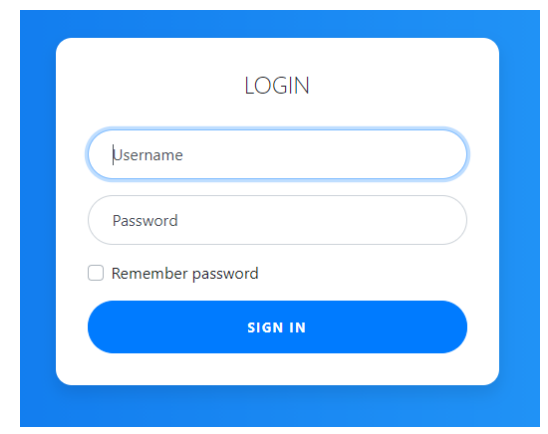

Gambar 13. Tampilan Login Admin 


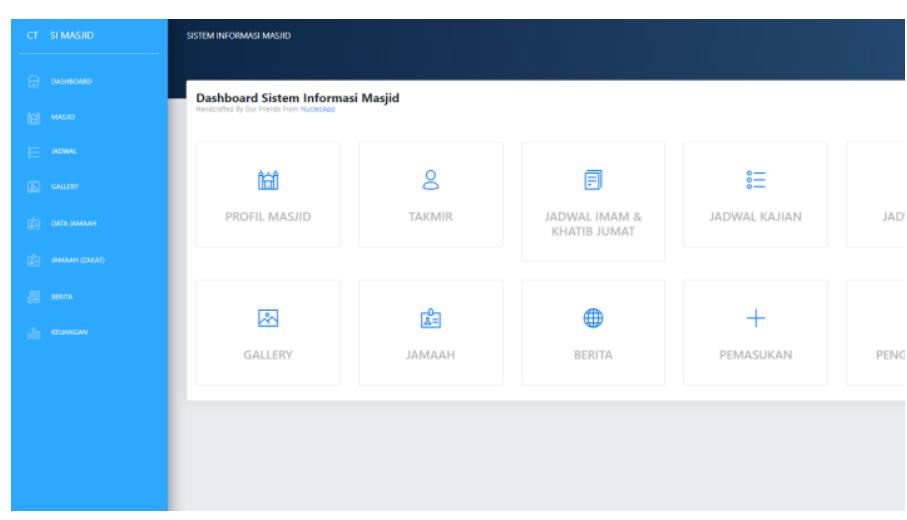

Gambar 14. Tampilan Back End

\section{Pengujian}

Pada tahap ini dilakukan pemodelan mengenai sistem yang dikembangkan. Terdapat beberapa diagram pemodelan yang dibuat, antara lain use case diagram, activity diagram, class diagram, data model, dan desain user interface. Functional test dengan pendekatan black box dilakukan untuk memastikan bahwa sistem dapat berjalan dengan sebagaimana mustinya dari sisi fungsionalitas. Tester melakukan pengujian dengan 76 skenario pengujian yang dibagi ke dalam 21 kategori. Tabel pengujian berisi kondisi, tindakan yang perlu dilakukan dalam proses pengujian, hasil yang diharapkan, dan hasil yang diperoleh. Tabel III menunjukkan beberapa hasil pengujian.

TABEL III HASIL FUNCTIONAL TEST

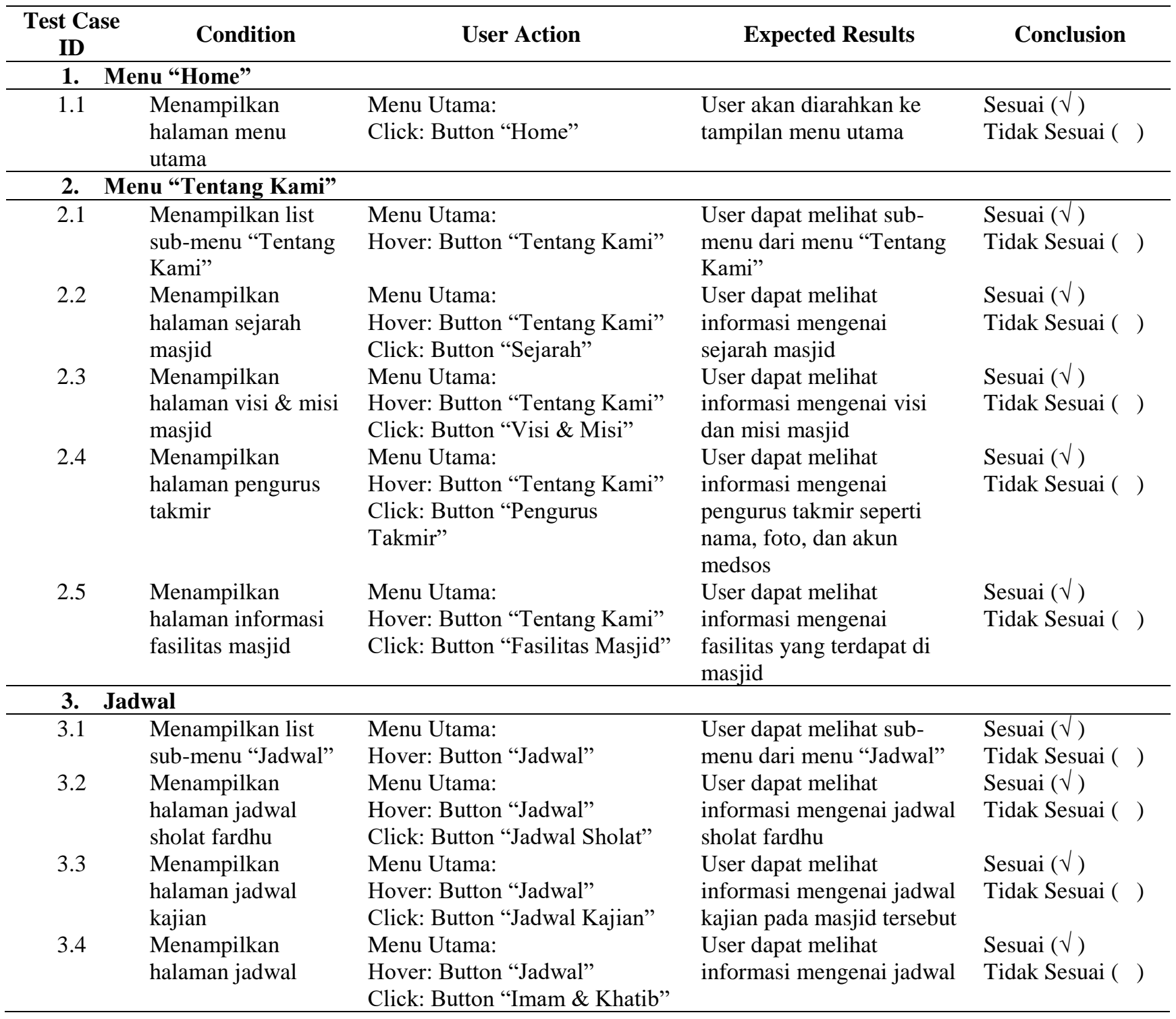




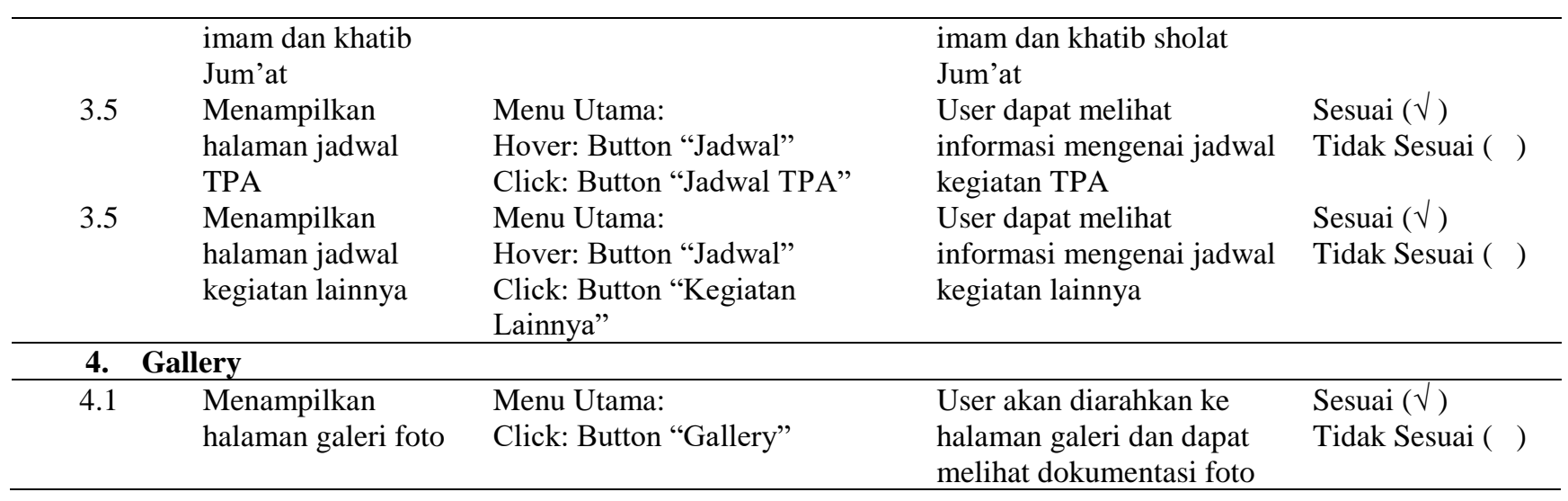

Berdasarkan hasil functional test dapat diketahui persentase kelayakan dengan menggunakan Formula (1).

$$
\begin{aligned}
& \text { Persentase Kelayakan (\%) } \\
& \quad=\frac{\text { Nilai Hasil Pengujian }}{\text { Nilai Maksimal }} \times 100 \%
\end{aligned}
$$

Persentase Kelayakan (\%) $=\frac{76}{76} \times 100 \%$

Persentase Kelayakan (\%) $=100 \%$

Hasil perhitungan persentase kelayakan mendapatkan nilai sebesar $100 \%$. Dengan demikian dapat dikatakan bahwa seluruh fitur aplikasi sistem informasi yang dikembangkan berhasil berjalan dengan baik sebagaimana mestinya. Berdasarkan hasil perhitungan persentase kelayakan aplikasi dari sisi fungsionalitas dapat disimpulkan bahwa aplikasi sistem informasi masjid layak untuk digunakan.

\section{PENUTUP}

Telah dikembangkan sistem informasi masjid berbasis website. Sistem yang dikembangkan memiliki fitur yang dapat membantu masjid untuk mengelola informasi, menyampaikan informasi dan media dakwah. Dengan memanfaatkan sistem informasi masjid, diharapkan pelayanan masjid terhadap jamaah akan lebih baik sehingga kepuasan jamaah akan meningkat. Pengujian yang dilakukan memperoleh persentase kelayakan sebesar $100 \%$ dari sisi fungsionalitas. Dengan demikian dapat dikatakan bahwa sistem informasi masjid yang dikembangkan layak untuk digunakan.

\section{UCAPAN TERIMA KASIH}

Ucapan terima kasih kepada Universitas Ahmad Dahlan yang telah memberikan dukungan finasial berupa hibah penelitian dan kepada pihak Takmir Masjid Baiturrahim Gejayan yang telah bersedia menjadi lokasi penelitian sehingga penelitian ini dapat terlaksana dengan baik. Semoga penelitian yang telah dilakukan dapat memberikan manfaat.

\section{DAFTAR PUSTAKA}

Ali, S. (2009). Pengertian Masjid. Almanhaj.or.Id. https://almanhaj.or.id/2524-pengertian-masjid.html

APJII. (2018). Penetrasi \& Profil Perilaku Pengguna Internet Indonesia 2018. Apjii, 51. www.apjii.or.id

binus.ac.id. (2016). Pengertian Sistem Informasi. http://scdc.binus.ac.id/himsisfo/2016/07/pengertian -sistem-informasi/

Fahruddin, I., \& Azam, M. N. Al. (n.d.). Sistem Informasi Kegiatan Masjid Berbasis Mobile Web (Studi Kasus : Masjid Nurul Anwar Perumahan Bumi Citra Fajar Sidoarjo ).

Irawan, A. W., Yusufianto, A., Agustina, D., \& Dean, R. (2020). Laporan Survei Internet APJII 2019-2020 $(Q 2)$.

Iyawe, S. (2019). Advantages of Model View Controller. Codeupset Ltd. Custom.

https://www.codeupset.com/advantages-of-modelview-controller/

Mubarok, I. (2018). Manfaat Website Untuk Pribadi, Bisnis, dan Masyarakat. Niagahoster. https://www.niagahoster.co.id/blog/manfaatwebsite/

Mukhtar, U. (2020). Umat Islam Harus Temukan Strategi Adaptasi Dunia Digital. Republika.Co.Id. https://www.republika.co.id/berita/q411r0366/umat -islam-harus-temukan-strategi-adaptasi-duniadigital

Prabowo, I. J. K. G., Setiawan, A., \& Prakoso, S. T. (2013). Pengembangan Sistem Mobile Journal Berbasis Android Untuk Referensi Belajar 
Mahasiswa Di Lingkungan Fakultas Ekonomi UNY. Program Kreativitas Mahasiswa - Karsa Cipta 2013, 1-3.

http://artikel.dikti.go.id/index.php/PKMKC/article/ view/122

Rayo, L. (2015). Modified Waterfall Model. Prezi Inc.

Rokhman, A. (2017). Perancangan Web Masjid Raudhatul Jannah Makassar. 8(3), 167-173.

Scalia, S. (2020). What Are Information Systems? Study.Com.

https://study.com/academy/lesson/what-are- information-systems-definition-types-quiz.html

Triwidiyanto, A. (2010). Perkembangan Teknologi Web 1.0 ke Web 2.0. Kompasiana.Com.

https://www.kompasiana.com/andrejo/55004b5ea3 3311926f510a1c/perkembangan-teknologi-web-10-ke-web-2-0

Wahyudi, S. E. (2015). Sistem Pemrograman Model View Controller. Universitas Ciputra. https://informatika.uc.ac.id/2016/12/sistempemrograman-model-view-controller-mvc/ 